\title{
THE JENCKS LEGISLATION: PROBLEMS IN PROSPECT
}

DISCOVERY through legal process has long been governed by rules judicially established. ${ }^{1}$ Recognizing the need for flexible control of adjudicatory procedures, the federal courts have traditionally exercised a broad, almost legislative discretion in formulating principles of adjective law. Thus, they have held the usual restraints of stare decisis inapplicable to procedural determinations $^{2}$ and have continually modified existing regulation when necessary to more just and effective judicial administration of the law. ${ }^{3}$ Moreover, Congress, giving further status to judicial expertise in the conduct of legal proceedings, has allowed the Supreme Court to formulate the basic regulation of federal court practice-the Federal Rules of Civil and Criminal Procedure.*

1. Gordon v. United States, 344 U.S. 414, 418 (1953); Funk v. United States, 290 U.S. 371 (1933). The Supreme Court's intrinsic power in this area is illustrated by Hickman v. Taylor, 329 U.S. 495 (1947). There, the Court established the rule that a party to a civil proceeding might obtain statements of a witness taken by opposing counsel if a showing of necessity was made. At the time, an amendment to the Rules of Civil Procedure which would have effected the same change was pending before the Court. The holding effectively circumvented the statutory procedure for amendment with its requirement that all modifications of the rules be approved by Congress. See 4 MFoore, Federai Practice $\llbracket 26.23$ [6], at 1126-27 (2d ed. 1950). But see Indiviglio v. United States, 249 F.2d 549 (5th Cir. 1957) (Supreme Court has no rule-making power in this area apart from that expressly given it by Congress).

2. "[A] rule of evidence at one time thought necessary to the ascertainment of truth should yield to the experience of a succeeding generation whenever that experience has clearly demonstrated the fallacy or unwisdom of the old rule.

". . . O Of course, Congress has that power [to change an outmoded rule]; but if Congress fail to act, as it has failed in respect of the matter now under review, and the court be called upon to decide the question, is it not the duty of the court . . . to decide it in accordance with present day standards of wisdom and justice rather than in accordance with some outworn and antiquated rule of the past?" Funk v. United States, supra note 1, at 381-82. In Funk, the Court overruled the common-law inability of the wife of a criminal defendant to testify in her husband's behalf.

3. Communist Party v. Subversive Activities Control Bd., 351 U.S. 1.15 (1956) (remanding administrative determination presumably based on "tainted" evidence-testimony of reputed perjurer) ; Gordon v. United States, 344 U.S. 414, 418-19 (1953) (expanding a defendant's right to material in the prosecution's possession); McNabb v. United States, 318 U.S. 332 (1943) (excluding from evidence information obtained through misconduct of federal law enforcement officers); Weeks v. United States, 232 U.S. 383 (1914), discussed in Wolf v. Colorado, 338 U.S. 25 (1949) (excluding from evidence information obtained by federal officers in an unconstitutional search and seizure); United States v. Krulewitch, 145 F.2d 76 (2d Cir. 1944) (expanding a defendant's right to impeachment material in the government's possession).

4. 18 U.S.C. $\$ 3771$. (1952) ; 28 U.S.C. $\S 2072$ (1952). Under the procedure set out by these statutes, various bar committees recommended a draft of the rules to the Supreme Court, which studied, modified and adopted them subject to the approval of Congress. Congress approved both the civil and the criminal rules without substantial further modification. For a discussion of the adoption of the Federal Rules of Civil Procedure, see Clark, Code Pleading 31-45 (2d ed. 1947). On the adoption of the Federal Rules of 
In establishing rules for civil proceedings, the Court has granted the individual litigant wide discretion in utilizing legal process for discovery of information facilitating preparation of his case and for obtaining tangible evidence to be used at trial. ${ }^{5}$ The criminal defendant's corresponding rights are, however, far more rigidly prescribed. ${ }^{\circ}$ And discovery is especially restricted when the prosecution controls the desired documents; arguments of "effective law enforcement" and "enhanced national security" are then involked in justification. 7

Acting pursuant to its long-recognized judicial authority, the Supreme Court in Joncks $v$. United States enlarged a criminal defendant's right of access to government documents useful for cross-examination of prosecution witnesses. ${ }^{8}$ The documents allowed the defense were statements made to the Federal Bureau of Investigation, and the defendant was an alleged communist conspirator. General misinterpretation of the scope and content of the decision,

Criminal Procedure, see Dession, The New Federal Rulcs of Criminal Procedure: I, 55 YALE L.J. 694-98 (1946).

Criminal rule 26 expressly reaffirms the discretionary power of the courts, as defined by Funk v. United States, 290 U.S. 371 (1933), to prescribe rules of evidence. See Berge, The Proposed Federal Rules of Criminal Procedure, 42 Mrcr. L. Rev. 353, 354 (1943).

5. For a complete description of these provisions, see Pike \& Willis, The Nez Federal Deposition-Discoz'ery Procedure, 38 Colcu. L. Rev. 1179, 1436 (1938); Pike \& Willis, Federal Discovery in Operation, 7 U. CHI. L. Rev. 297 (19+0) : Holtzoff, Instruments of Discoz'ery Under Federal Rules of Ciiril Procedure, 41 Micr. L. Rev. 205 . (1942).

6. For discussion of discovery procedure in criminal cases, see notes 60-89 infra and accompanying text.

7. For cases particularly restricting the scope of discovery against the government, see note 13 infra.

An eminent trial judge has explained and justified the dichotomy between civil and criminal discovery proceedings as follows: "In a complex society, in which those accused of crime have unbounded opportunity of avoiding detection and prosecution, the interests of society, in protecting itself against the anti-social forces, demands that some element of surprise be left. And I venture to say that even the most liberal would not advocate, in the realm of criminal procedure, the broad means of discovery which the civil rules now embody as an accepted policy." Yankwich, Concealment or Revealment?, 3 F.R.D. 209, 210-11 (1943).

See also United States v. Garsson, 291 Fed. 646, 649 (S.D.N.Y. 1923) (dealing with grand jury transcripts); Hoover, The Confidential Nature of FBI Reports, 8 SyRacuse L. Rev. 2,7 (1956); Hoover, Hoover Answers Ten Questions on the FBI, N.Y. Times Magazine, April 16, 1950, pp. 9, 31-32.

Some commentators, on the other hand, have found no basis to justify the distinction existing between civil and criminal discovery and have advocated liberalized procedures for the criminal law. Comment, Pre-Trial Disclosure in Criminal Cases, "60 Y YLE L.J. 626 (1951).

The government has resisted discovery against itself in the civil as well as the criminal field. Its efforts in the former have met with little success even where common-law privileges were involved. CLaRK, Code Pleading 57.1 n.268 (2d ed. 1947); see Berger \& Krash, Government Innmuntity From Discovery, 59 Yale L.J. 1451 (1950).

8. 353 U.S. 657 (1957). 
in addition to the explosive circumstances of the case, led to stormy public reaction and harsh criticism of the Court. Spurred to immediate action by the intense public interest, Congress sought to enact legislation which would prevent Jencks from exceeding the reach of its narrow holding. Unfortunately, with recess fast approaching, haste was a prerequisite to legislation. As a result, the statute which finally emerged from the original, overly zealous limitation on discovery proposed by the Department of Justice contains ambiguities in some respects and, geared as it is to the fact situation presented by Jencks, appears to foreclose other discovery proceedings important to the defense and not contemplated by the Court.

\section{The Jencks Deciston}

A prosecution for filing false noncommunist affidavits with the NLRB, ${ }^{9}$ Jencks v. United States is significant in the procedural standards it established for defense examination of government documents. The primary controversy on appeal concerned the trial court's refusal to allow the defense relevant FBI reports of two highly important prosecution witnesses. ${ }^{10} \mathrm{On}$ cross-examination, the witnesses admitted making these reports, and, in conformity with prevailing practice, the defense requested that they be examined by the court and that those portions found inconsistent with the witnesses' testimony be submitted to the accused for use at trial.11 Arguing that prior to production defendant must establish variance between the witnesses' testimony and the documents requested, the Fifth Circuit affirmed the trial court's denial of defendant's motion. ${ }^{12}$ The Supreme Court reversed, expressly disclaiming any need for a showing of inconsistency to obtain relevant matter. Although a foundation relating the material sought to the testimony ques-

9. Section $9(\mathrm{~h})$ of the Taft-Hartley Act requires each officer of a labor union to file with the NLRB an affidavit stating that he is not a member of, or affiliated with, the communist party. 61 STAT. 146 (1947), as amended, 29 U.S.C. $\$ 159(\mathrm{~h})$ (1952). Jencks, a union leader who filed such an affidavit, was prosecuted under 18 U.S.C. $\$ 1001$ (1952), which makes it a felony to give false information to the government.

10. These witnesses were J. W. Ford and the notorious Harvey F. Matusow. See note 74 infra. Both were undercover agents of the FBI. 353 U.S. at 659 . The importance of their testimony is evident from the subsequent disposition of the case. After the Supreme Court ordered a new trial, the government abandoned its prosecution, since Matusow was no longer available as a witness. See N.Y. Times, Jan. 2, 1958, p. 15, cols. 1-5.

11. See notes 13,21 infra.

12. 'Jencks v. United States, 226 F.2d 540, 552 (5th Cir. 1955). Although some courts have required such a showing from the defendant, see note 13 infra, the Fifth Circuit erroneously based its decision on Shelton v. United States, 205 F.2d 806 (5th Cir.), cert. dismissed, 346 U.S. 892 (1953). In that case, the trial judge examined the specified statements without requiring the defendant to show that they were inconsistent with the witness's trial testimony. However, the defendant was not allowed to see the statements after the trial judge found them not inconsistent with the trial testimony. Id. at S14. The Fifth Circuit has recently implied that it erred in holding that the defendant had not made the necessary showing of inconsistency in Jencks. Indiviglio v. United States, 249 F.2d 549, 563 (1957). 
tioned was necessary, a requirement of contradiction, the Court reasoned, would be equivalent to denying the defense relevant and material evidence. Unless the witness should actually admit an inconsistency, the accused would be unable to know or discover the conflict without inspecting the reports.

The rationale underlying the Fifth Circuit decision thus invalidated, the Supreme Court proceeded more broadly to establish rules governing the availability of government documents for cross-examination of prosecution witnesses. In answer to the government's assertion of privilege for reports of a confidential nature, the Court stated that initiation of a prosecution waives all such privileges to the extent that documents are relevant to the accused's defense. The Court ruled further that the defense must have access to all relevant documents irrespective of their admissibility in evidence. An initial testing of admissibility by the trial judge, as had been requested by the defense, was accordingly found unnecessary and disapproved. Since the accused is best able to determine the use to be made of relevant data, the prosecution must turn over directly to him all prior statements of the witness logically related to testimony on direct examination. Only when the material is to be introduced into evidence need the trial judge examine the documents and make rulings based on evidentiary standards. Finally, the court held that, where the prosecution is unwilling to conform to the procedure so established, the case must be dismissed.

Whether viewed against the background of earlier judicial decisions or evaluated in light of the conflicting values in equitable adjudication and effective law enforcement, the Jencks opinion appears justifiable. Rarely has a court required that the accused establish a foundation of inconsistency prior to inspection of government documents. ${ }^{13}$ And the holding that the prosecution waives any privilege in relevant matter by initiation of suit conforms to a long-recognized series of decisions. ${ }^{14}$ In the only significant departure from

13. The following cases have required this preliminary showing: Herzog v. United States, 226 F.2d 561, 566-67 (9th Cir. 1955) (perhaps limited to grand jury transcripts) ; Scanlon v. United States, 223 F.2d 382, 385-86 (1st Cir. 1955) ; United States v. Dilliard, 101. F.2d 829, 837 (2d Cir. 1938), cert. denied, 306 U.S. 635 (1939); United States v. Rosenfeld, 57 F.2d 74, 76 (2d Cir. 1932). On the other hand, numerous decisions have dispensed with the requirement as a prerequisite to inspection by the court. See Scales v. United States, 227 F.2d 581, 592 (4th Cir. 1955), rev'd on other grounds, 355 U.S. 1 (1957) ; United States v. Lebron, 222 F.2d 531, 536 (2d Cir. 1955) ; Shelton v. United States, supra note 12; United States v. Simonds, 148 F.2d 177 (2d Cir. 1945) ; United States v. Ebeling, 146 F.2d 254 (2d Cir. 1944); United States v. Rosenberg, 146 F. Supp. 555, 561-62 (E.D. Pa. 1956), rez'd on other grounds, 245 F.2d 870 (3d Cir. 1957); United States v. Mesarosh, 116 F. Supp. 345, $349-50$ (W.D. Pa. 1953), rev'd on other grounds, 352 U.S. 1 (1956) (dictum) ; United States v. Schneiderman, 106 F. Supp. 731 (S.D. Cal. 1952). Occasionally, when a defendant had shown that a statement was inconsistent with the witness's trial testimony, the courts have held that the denial of the statement, while error, was harmless. E.g., Boehm v. United States, 123 F.2d 791, 80607 (8th Cir. 1941), cert. denied, 315 U.S. 800 (1942).

14. United States v. Andolschek, 142 F.2d 503, 506 (2d Cir. 1944); see cases cited note 13 supra, both those requiring inconsistency and those dispensing with the require- 
previous practice, the Court removed the trial judge as initial exciser of inadmissible material and allowed defendant inspection of all statements related to the subject matter of direct examination. Even this holding is not unprecedented. ${ }^{15}$

The Court's attitude is summarized in a paragraph of the decision:

"The practice of producing government documents to the trial judge for his determination of relevancy and materiality, without hearing the accused, is disapproved. Relevancy and materiality for the purposes of production and inspection, with a view to use on cross-examination, are established when the reports are shown to relate io the testimony of the witness. Only after inspection of the reports by the accused, must the trial judge determine admissibility-e.g., evidentiary questions of inconsistency, materiality and relevancy-of the contents and the method to be employed for the elimination of parts immaterial or irrelevant."16

By expanding the test of inspection from admissibility in evidence to relevancy - logical relationship to testimony at trial - the Court permits the defendant to examine a broad group of documents previously denied him, documents relevant as logically related to the witness's testimony but not meeting evidentiary standards of "inconsistency, materiality and relevancy." This enlargement is limited, however; irrelevant portions of partially relevant documents may not be viewed by the accused. In stating that "elimination of parts immaterial or irrelevant" should be effected "only after inspection of the reports by the accused," the Court can be referring only to evidentiary determinations of relevancy and materiality. Since the prosecution privilege is waived only to the extent that documents touch relevant testimony, ${ }^{17}$ no intent to prevent initial excision of independent portions by the prosecution can be imputed to the Court.

ment. Since the Andolschek case, only one decision, Kaufman v. United States, 163 F.2d 404 (6th Cir. 1947), seems to deny a defendant's right to see a witness's prior inconsistent statements in the possession of the government.

15. In the trial of Aaron Burr, Chief Justice Marshall allowed the defendant to obtain from the President of the United States relevant portions of a letter even though they contained state secrets and might not have been admissible in evidence. "In regard to the secrecy of these parts which it is stated are improper to give out to the world, the court will take any order that may be necessary. I do not think that the accuscd onght to be prohibited from seeing the letter; but, if it should be thought proper, I will order that no copy of it be taken for public exhibition, and that no use shall be made of it but what is necessarily attached to the case. After the accused has secn it, it will yet be a question whether it shall go to the jury or not." United States v. Burr, 25 Fed. Cas. No. 14694, at 192 (C.C. Va. 1807). (Emphasis added.) See discussion of this case in Berger \& Krash, supra note 7, at 1456-59. See also Fryer v. United States, 207 F.2d 134 (D.C. Cir. 1953) (allowing pretrial discovery of documents which would be admissible if they proved inconsistent with the witness's testimony at the trial).

16. 353 U.S. at 669 . (Emphasis added.)

17. The Court approved the statement in United States v. Andolschek, 142 F.2d 503, 506 (2d Cir. 1944): "So far as they directly touch the criminal dealings, the prosecution necessarily ends any confidential character the documents may possess . . ." 353 U.S. at 671 . 
So construed, Jencks represents the logical culmination of a line of cases establishing the compass of the criminal defendant's right of discovery. Originally, disclosure of the contents of government reports was limited to oral discovery through examination in court $;^{18}$ visual inspection of prosecution documents was confined to statements actually viewed by a witness while questioned at trial. ${ }^{19}$ The initial inroad on this limitation occurred in United States $v$. Andolschek. ${ }^{20}$ There, the prosecution was not permitted to withhold, under a claim of privilege, government records which the accused sought to place in evidence in his own behalf. Relying on considerations of fairness, the court forced the government to choose between abandoning the prosecution or disclosing the documents so far as they directly touched the dealings on which the prosecution was founded. While Andolschek concerned documents admissible in evidence under an exception to the hearsay rule and desired by the defendant for his case in chief, subsequent cases applied its reasoning to impeachment materials. Emphasizing the defendant's right to place the documents in evidence rather than to inspect, these cases established the practice of initial in camera inspection by the trial judge to allow the defense only those documents meeting evidentiary standards of admissibility. ${ }^{21}$ In Gordon $v$. United States, however, the Court recognized that a document's usefulness to the defense need not be limited by evidentiary rules: "Demands

18. Boehm v. United States, 123 F.2d 791, 805-06 (8th Cir. 1941), cert. denied, 315 U.S. 800 (1942) (defendant may question witness about the contents of a statement but may not inspect the statement itself); Heard v. United States, 255 Fed. 829 (8th Cir. 1919) (defendant may question witness about the contents of the statement). For a discussion of the evidentiary privileges the government has in such material under common law and under statute, see Berger \& Krash, supra note 7; Donnelly, Judicial Control of Informants, Spies, Stool Pigeons, and Agent Prozacateurs, 60 Y YLE L.J. 1091, 1095 n.13 (1951); Mitchell, Government Secrecy in Theory and Practice: "Rules and Regulations" as an Autonomous Screen, 58 CoLuM. L. Rev. 199 (1958) ; Sanford, Evidentiary Privileges Against the Production of Data Within the Control of Executive Departments, 3 VAND. L. Rev. 73 (1949); Notes, 58 YALE L.J. 993 (1949), 41 CoRnell L.Q. 737 (1956).

19. Documents used by a witness while on the stand were available to the defense. But, for a long period, inspection of government documents was largely confined to this circumstance. Presumably, a witness would most generally use such documents to refresh his recollection. Little v. United States, 93 F.2d 401 (Sth Cir. 1937), cert. denied, 303 U.S. 644 (1938) ; Goldman v. United States, 316 U.S. 129 (1942) (by implication). Some courts rationalized this limitation on the basis of privilege. United States $v$. Marino, 141 F.2d 771 (2d Cir. 1944); Arnstein v. United States, 296 Fed. 946 (D.C. Cir. 1924). Other courts required a strict prior showing that the statement was inconsistent with the witness's trial testimony. E.g., Arnstein v. United States, supra at 950. And these courts were likely to hold a refusal to allow discovery even after such a showing merely harmless error. Boehm v. United States, supra note 18. In Goldman v. United States, stipra, the Supreme Court denied that a defendant had any absolute right to these statements if a witness did not use them in court.

20. 142 F.2d 503 (2d Cir. 1944).

21. For cases applying this principle of disclosure, see United States v. Krulewitch, 145 F.2d 76 (2d Cir. 1944); cases cited note 13 supra. 
for production and offering in evidence raise related issues but independent ones, and production may sometimes be required though inspection may show that the document could properly be excluded."22 The defense was held entitled to inspection even though exclusion from evidence of the government documents it sought might not have been reversible error. The Jencks ruling that relevant documents be produced whether or not they could be introduced in evidence merely constitutes the logical extension of the Gordon rationale. If discovery can reach documents which, though admissible, may be excluded with impunity, logic dictates that it also extend to relevant records inadmissible in the first instance.

A balance of the values in equitable adjudication and effective law enforcement also reinforces the Jencks solution. Information contained in inadmissible records may be just as important for impeachment purposes as that revealed by admissible documents. The fact that evidence is not sufficiently inconsistent with, or material or relevant to, the testimony of a prosecution witness to be admissible need not mean that it cannot arm the accused with knowledge essential to neutralization of the challenged testimony and, perhaps, a resulting successful defense. Moreover, the rationale for shielding insufficiently inconsistent records from the jury-facilitating the progress of the trial-seems wholly inapplicable to insulate such information from the defendant. ${ }^{23}$ Similarly, the government's primary security interest-concealing the identity of informants-24 does not appear jeopardized by allowing the defense access to inadmissible documents. This aim is effectively abrogated when the declarant takes the witness stand.

\section{Public Uproar Created by Jencks}

Popular reaction to the Supreme Court's decision in Jencks was entirely out of proportion to the limited import of the holding. The dissenting opinion of Mr. Justice Clark established the tone of this reaction: "[T] hose intelligence agencies of our Government engaged in law enforcement may as well close up shop for the Court has opened their files to the criminal and thus afforded him a Roman holiday for rummaging through confidential information as well as vital national secrets."25 Sparked by this statement, the public widely misinterpreted Jencks as allowing far broader rights of discovery than were actually contemplated by the decision. ${ }^{26}$ So interpreting the case, the

22. 344 U.S. 414,418 (1953).

23. A copy of a witness's prior statement is inadmissible for impeachment purposes if it in no way contradicts the witness's testimony. E.g., United States v. Simonds, 148 F.2d 177 (2d Cir. 1945).

24. See statement of J. Edgar Hoover, quoted in text at note 27 infra.

25. 353 U.S. at 681-82. For reliance upon this interpretation of the case, see N.Y. Herald Tribune, June 5, 1957, p. 22, cols. 1-2; id. June 9, 1957, § 2, p. 2, cols. 3-4; Hartford Courant, June 4, 1957, p. 1, col. 5.

26. Even the President observed: "What they [the Justice Department] have opposed is the widespread opening of the F.B.I. files. In any one file in the F.B.I. records, fifteen 
public severely criticized the Court for assuming an irresponsible attitude toward national security and allowing broad investigation of confidential records. The press in particular was responsible for generating such misconstruction.

"In a sharp warning on the sad effects a United States Supreme Court will have in the Nation's struggle against crime, Mr. Hoover has spoken out strongly on the necessity for protecting FBI files, and the identities of confidential informants contained in the files, and preventing them from being delivered over to the enemy-the accused criminal.

"In the Jencks case, the Supreme Court rules such files must be delivered in their entirety to the defense, without any screening by the presiding judge to determine what is confidential, and dangerous in the hands of anyone except the official law enforcement agency which captured the accused criminal.

"Said the FBI chief: 'the very basis of our success in safeguarding America's domestic security is the FBI's assurance to this country's citizens that the information they give will be maintained in the strictest confidence." "27

Some legislators appeared equally outraged:

"The FBI files ... were in effect declared sitting ducks in an open hunting season by the Supreme Court of the United States in the nowfamous Jencks case ... . The Court, in effect, told every criminal and his lawyer that they have the right to examine the files of the Federal Bureau of Investigation if they think that through such examination they can find documentary support for whatever nefarious position they choose to take .... Under the new Court edict, this mass of material is open to the praying [sic] eyes of lawyers and outright criminals-men who could and would use it to their own advantage and without regard for those whom it might needlessly hurt."28

In light of the narrow scope of the decision and the undramatic change it effected, the basis for the general misconstruction and criticism of Jencks is unclear. Often, the case was used as a foundation from which to criticize

people may be mentioned, some of them only once and in most derogatory fashion, because somebody that didn't like a man in a little village can say 'Well he is a skunk, or worse, and it will be down there in the report submitted by the individual. You could do incalculable damage, to my mind, just by opening up the F.B.I. files. It would be terrible." N.Y. Times, July 18, 1957, p. 12, cols. 3-4.

27. Editorial, Los Angeles Evening Herald Express, Aug. 1, 1957, reprinted in 103 Cong. Rec. A6406 (daily ed. Aug. 7, 1957). See also, Time, June 17, 1957, p. 19 ("[The Jencks decision] knocked over applecarts all across the U.S. security scene"); Editorial, Glendale [Cal.] News-Press, July 16, 1957, reprinted in 103 CoNG. REc. A5750 (daily $\in d$. July 17, 1957) ; $A$ Subversive Court, Methodist Challenge, Sept. 1957, reprinted in 103 Conc. REC. A6709 (daily ed. Aug. 15, 1957).

28. Remarks of Representative Collier of Illinois, printed in id. at A5514-15 (daily ed. July 10, 1957). See also remarks of Senator Potter, id. at 9600-01 (daily ed. July 1, 1957) ; Representative Burdick, id. at 14722-23 (daily ed. Aug. 27, 1957). 
broadly the Court's recent liberal decisions, particularly the segregation cases. $^{29}$ More specifically, misinterpretation may in part be explained by ambiguities in the decision; despite its necessary import, the language does not clearly indicate whether or not the prosecution may excise irrelevant portions of relevant documents. ${ }^{30}$ Perhaps more basic was the fear that any discovery against the government might impinge upon national security. ${ }^{31} \mathrm{On}$ this view, Jencks was objectionable for expanding an already unpopular practice.

\section{Congressional Reaction and the Administration Proposal}

Congressional response to the Jencks decision was not, on the whole, as irrational as the more general popular reaction. The legislators found no need to eradicate the accused's right of discovery against the government, or even to reverse the rule established by Jencks. In their view, the policy enunciated by the case was valid. ${ }^{32}$ But political pressures resulting from public disquietude dictated clarification of the decision. ${ }^{33}$ Clarification was also thought necessary to eliminate judicial misconstruction of decisional ambiguities; Congress, although on very limited information, believed that lower federal courts were misinterpreting Jencks and allowing unjustifiable intru-

29. See, e.g., Santa Monica California Evening Outlook, July 3, 1957, reprinted in 103 Cong. Rec. A5466 (daily ed. July 9, 1957) : "Congress should enact this measure [the Jencks bill] speedily. It should also pass other and tighter laws until all the mischief created by the Supreme Court's ill-advised decisions is nullified."; Mr. Brozoncll Finds "the Law of the Land" Entirely Unacceptable, Jackson [Miss.] Clarion Ledger, July 16, 1957, reprinted in 103 CoNG. Rec. A6692 (daily ed. Aug. 15, 1957); Brovenell's Court Loyalty Turns Into Quick Defiance, Nashville Tennessean, July 23, 1957, reprinted in 103 CoNG. Rrc. A6692 (daily ed. Aug. 15, 1957).

30. See notes 16-17 supra and accompaniying text.

31. See, e.g., quotations in text at notes $27-28$ supra.

32. "[T]he proposed legislation ... reaffirms the decision of the Supreme Court in its holding that a defendant on trial in a criminal prosecution is entitled to reports and statements in possession of the Government touching the events and activities as to which a government witness has testified at the trial.

"The purpose of the proposed legislation is to establish a procedural device that will provide such a defendant with authenticated statements and reports of Government witnesses which relate directly upon his testimony.

"The committee is convinced that the proposed legislation which is procedural in character, if enacted, will serve both to protect individual rights during criminal prosecutions and to protect confidential information in the possession of the Government." S. REp. No. 569, 85th Cong., 1st Sess. 2 (1957). See also S. Rep. No. 981, 85th Cong,, 1st Sess. (1957) ; H.R. Rep. No. 700, 85th Cong., 1st Sess. (1957) ; remarks of Senator O'Mahoney, 103 CoNG. Rec. 9896 (daily ed. July 8, 1957).

33. "The reason the bill is being introduced today is that there has been considerable misinterpretation in the press and even in the courts as I see it, of the decision which was handed down by the Supreme Court on June 3, 1957, in the case of Clinton E. Jencks, petitioner, versus the United States of America." Remarks of Senator O'Mahoney. id. at 9095 (daily ed. June 24, 1957). See notes 25-28 supra. 
sions into confidential files which required the government to discontinue initiated prosecutions. ${ }^{34}$

34. See, e.g., H.R. REp. No. 700, 85th Cong., 1st Sess. 7-13 (1957) ; S. Rep. No. 981, 85th Cong., 1st Sess. 7-12 (1957).

None of the three circuit courts which interpreted Jencks prior to passage of the act had any difficulty keeping the decision within bounds. United States v. Killian, 246 F.2d 77 (7th Cir. 1957) (discovery allowed on facts comparable to Jencks); United States v. Rosenberg, 245 F.2d 870 (3d Cir. 1957) (discovery of grand jury transcript allowed on facts comparable to Jencks) ; Simms v. United States, 248 F.2d 626 (D.C. Cir. 1957) (denying discovery of irrelevant matter).

Because many of the district court interpretations of Jencks have not been embodied in reported opinions, a complete survey is not possible. The cases brought to Congress's attention, however, do not support its conclusion of widespread judicial misinterpretation of the Jencks decision. A Statement by Attorney General Brownell, S. REp. No. 569, 85th Cong., 1st Sess. 4-S (1957); the appendix to S. ReP. No. 981, 85th Cong., 1st Sess. (1957); and a brief by Senator O'Mahoney, printed in 103 Cong. REc. 14550-54 (daily ed. Aug. 26, 1957), discuss some eighteen district court interpretations of the Jencks decision. These decisions were branded as the most extreme examples of misconstruction of the case. But only four of the eighteen cases allowed the defense to see portions of documents not relevant for impeachment purposes. United States v. Stanley, Crim. No. 21113, N.D. Ga., July 8, 1957; United States v. White, Crim. No. 22028, N.D. Ga., July 18, 1957; United States v. Clark, discussed in 103 Cong. REc. 14552 (daily ed. Aug. 26, 1957); United States v. Erie Malt Beverage Distributing Ass'n, discussed in $i b i d$. In four additional cases, the court ordered the prosecution to turn over to the defense relevant but unadopted summaries of prior statements of a witness. United States v. Morgan, discussed in id. at 14553; United States v. Nardollilo, discussed in ibid.; a narcotics prosecution in Georgia, discussed in S. REP. No. 569, 85th Cong., 1st Sess. 6 (1957); a prevailing wage violation in Georgia, discussed in S. REP. No. 981, 85th Cong., 1st Sess. 7-8 (1957). Some proponents of remedial legislation strongly disapproved of this practice. See, e.g., Statement of Attorney General Brownell, S. REP. No. 569, 85th Cong., 1st Sess. 6-7 (1957) ; H.R. Rep. No. 700, 85th Cong., 1st Sess. 5-6 (1957). However, Jencks had found the defense entitled to view such statements. 353 U.S. at 668.

Two courts ordered pretrial discovery of all statements relating to the planned testimony of witnesses the prosecution definitely expected to call at trial. However, the prosecution was free to add additional witnesses as its preparations for trial continued. And in neither case did the court allow the defendant to see statements which he would not ultimately have a right to see under the narrowest reading of Jencks. United States v. Apex Distributing Co., Crim. No. 49639, W.D. Wash., July 8, 1957; United States v. Hall, 153 F. Supp. 661 (W.D. Ky. 1957).

In all of the condemned cases, the prosecuting attorneys, under direct telephone instructions from Washington, refused to comply with the trial court's order. No case involved an erroneous court order exposing information which would affect the national security. Most of the disputed information seems of the most trivial significance. In United States v. White, supra, for example, the prosecution suffered a dismissal rather than turn over to the defendant information dealing with a second check forgery allegedly committed by the defendant which the government had presumably decided not to prosecute because one of the key witnesses to the crime had died. See discussion in 103 Cong. Rec. 14552 (daily ed. Aug. 26, 1957).

Moreover, the prosecuting attorneys have been accused of misstating the scope of district court determinations. In the course of ruling on the defendant's motion in United States v. White, supra, the trial judge addressed the prosecuting attorney as follows: 
While represented as achieving the desired clarification, ${ }^{35}$ the original bill, drafted by the Justice Department, contained ambiguous language broad enough to have severely eroded the criminal defendant's right of discovery against the government. Initially, the bill declared:

"In any criminal prosecution brought by the United States, any rule of court or procedure to the contrary notwithstanding, no statement or report of any ... person other than the defendant which is in the possession of the United States shall be the subject of subpena, discovery, or inspection, except as provided in paragraph (b) of this section." ${ }^{3}$

Not limited to statements made expressly to the government, or by a prospective government witness, or to those of a confidential nature, "statement or report," if broadly construed, could include nearly any form of documentary evidence which the government might obtain either voluntarily or by seizure or process. Within that context, the reference to "rule . . to the contrary notwithstanding" would jettison as to the extensive class of material embraced by "statement or report" not only the reforms resulting from Jencks but the procedures defined by the federal rules even prior to that case.

All previously existing methods by which a defendant might have obtained any "statement or report" thus discarded, paragraph (b) of the bill allowed inspection of "reports or statements of the [government's] witness . . relating to the subject matter as to which the witness has testified." 37 Moreover, on the theory that a witness should not be impeached by unauthenticated statements, discovery was further restricted to documents actually signed or adopted by the witness even though the Court in Jencks had ruled to the contrary. ${ }^{38}$ Combined with a broad interpretation of paragraph (a), these limitations would effectively have eliminated a defendant's pre-Jencks right to discover government documents for use in preparing his case in chief.99 Since the discoverable documents need relate to the subject matter of the government's direct examination, and are obtainable only after completion of

"Now, when you hold your press conference, and when you talk to Washington, be very careful, please, sir, not to state to the press, nor to Washington, that this Court has ordered you and directed you to deliver to defense counsel your entire file, because the Court has not done so-in this case nor in any other case. I am advised by Judge Hooper and by Judge Johnson that neither of them did any such thing in their cases, yet reports went out from your office that I had done so, that Judge Johnson had done so, that Judge Hooper had done so. . . . All of those reports were erroneous. Neither Judge has ever held any such thing:" Transcript of Record, United States v. White, stipra.

35. See, e.g., Statement of Attorney General Browne1l, S. ReP. No. 569, 85th Cong., 1st Sess. 4 (1957). Compare note 33 supra.

36. The full text of the bill is printed in S. REP. No. 569, 85th Cong., 1st Sess. 10.11 (1957), and in H.R. REP. No. 700, 85th Cong., 1st Sess. 15 (1957).

37. Ibid.

38. 353 U.S. at 668 .

39. For a discussion of the federal rules applicable to discovery of information for a defendant's case in chief, see notes 60-62 infra and accompanying text. 
such testimony, they should be of little utility except for impeachment purposes. Again, the limitation to signed or adopted statements would have combined with the absolute prohibition of paragraph (a) to render the Jencks reforms meaningless. A law enforcement agency would have little inducement to require signed reports. A witness conveying information to the government is under equal compulsion to be truthful whether or not he signs his statement. Section 1001 of the Federal Criminal Code, which defines as a felony the giving of false information to the government, is applicable both to signed and unsigned statements. ${ }^{40}$ Consequently, compelling a witness to sign his statements would benefit only the defense by allowing him information with which to impeach a government witness.

\section{The Jencks Legrslation}

Over the objection of the Administration, ${ }^{41}$ the broad and ambiguous language of the original bill was considerably modified to conform more closely to the Supreme Court's ruling in Jencks. As finally adopted, the act declares:

"(a) In any criminal prosecution brought by the United States, no statement or report in the possession of the United States which was made by a Government witness or prospective Government witness (other than the defendant) to an agent of the, Government shall be the subject of subpena, discovery, or inspection until said witness has testified on direct examination in the trial of the case.

"(b) After a witness called by the United States has testified on direct examination, the court shall, on motion of the defendant, order the United States to produce any statement (as hereinafter defined) of the witness in the possession of the United States which relates to the subject matter as to which the witness has testified. If the entire contents of any such statement relate to the subject matter of the testimony of the witness, the court shall order it to be delivered directly to the defendant for his examination and use.

"(c) If the United States claims that any statement ordered to be produced under this section contains matter which does not relate to the subject matter of the testimony of the witness, the court shall order the United States to deliver such statement for the inspection of the court in camera. Upon such delivery the court shall excise the portions of such statement which do not relate to the subject matter of the testimony of

40. 18 U.S.C. $\$ 1001$ (1952). This statute has been interpreted to apply to ordinary statements made to a government investigator in the course of an investigation. Cohen v. United States, 201 F.2d 386 (9th Cir. 1953) (written statement to government tax investigator) ; $c f$. Marzani v. United States, 168 F.2d 133 (D.C. Cir.), aff'd per curiam by an equally divided Court, 335 U.S. 895 (1948) (voluntary statement by government worker to superior in hearing concerning request for worker's resignation). But see United States v. Levin, 133 F. Supp. \& (D. Colo. 1953) (statute held inapplicable). See also note 9 supra.

41. Even after the senate debates had pointed out the breadth of the original draft's sweeping provisions, the Justice Department urged Congress to pass it without modification. See, e.g., letter from Attorney General (then Deputy Attorney General) Rogers to Representative Keating of New York, 103 Cong. Rec. 14720 (daily ed. Aug. 27, 1957). 
the witness. With such material excised, the court shall then direct delivery of such statement to the defendant for his use. If, pursuant to such procedure, any portion of such statement is withheld from the defendant and the defendant objects to such withholding, and the trial is continued to an adjudication of the guilt of the defendant, the entire text of such statement shall be preserved by the United States and, in the event the defendant appeals, shall be made available to the appellate court for the purpose of determining the correctness of the ruling of the trial judge. Whenever any statement is delivered to a defendant pursuant to this section, the court in its discretion, upon application of said defendant, may recess proceedings in the trial for such time as it may determine to be reasonably required for the examination of such statement by said defendant and his preparation for its use in the trial.

"(d) If the United States elects not to comply with an order of the court under paragraph (b) or (c) hereof to deliver to the defendant any such statement, or such portion thereof as the court may direct, the court shall strike from the record the testimony of the witness, and the trial shall proceed unless the court in its discretion shall determine that the interests of justice require that a mistrial be declared.

"(e) The term 'statement' as used in subsections (b), (c), and (d) of this section in relation to any witness called by the United States, means-

"(1) a written statement made by said witness and signed or otherwise adopted or approved by him; or

"(2) a stenographic, mechanical, electrical, or other recording, or a transcription thereof, which is a substantially verbatim recital of an oral statement made by said witness to an agent of the Government and recorded contemporaneously with the making of such oral statement." 42

Thus formulated, the act overcomes certain failings of the original bill, but ambiguities persist. The rigid prohibition of the initial paragraph (a) is considerably relaxed. Instead of the former broad insulation of any statement or report from discovery, only those statements made by a government witness and to a government agent are immunized. Further, the prohibition of new paragraph (a) is limited to inspection before the witness testifies at trial. After that time, paragraph (e) clearly renders authenticated statements subject to discovery under the act.

\section{Discovery of Authenticated Statements}

Paragraphs (b) and (c) establish the procedure by which the defense may obtain signed and adopted written statements, or substantially verbatim transcripts of oral statements, made by a witness. The procedure so prescribed preserves as to such statements the underlying rights, if not the identical procedures, dictated by Jencks. Once a prosecution witness has testified upon direct examination, the accused may demand from the government all relevant reports of that witness. No initial foundation of inconsistency is necessary.

42. 18 U.S.C.A. $\$ 3500$ (Supp. 1957). 
And, prior to production, the trial court is not required to examine the statements to determine whether or not they meet evidentiary standards of admissibility. Only if the prosecution contends that both relevant and irrelevant information is contained in a single document does any requirement of examination prior to production arise. In this event, the inspection is directed to standards of relevancy, not to evidentiary standards as was the pre-Jencks practice. The trial judge must convey to the defense all segments of documents "relating to the subject matter of the testimony of the witness"-in essence, the test of relevancy defined by Jencks. ${ }^{43}$

Although a controversial issue in the congressional debates, this provision for an in camera procedure to determine relevancy should not be constitutionally questionable. ${ }^{44}$ The Jencks decision necessarily granted the prosecution the right to edit irrelevant matter prior to defense examination of relevant documents; the government's privilege was not waived as to irrelevant information. ${ }^{45}$ The in camera procedure disapproved in that case was examination directed toward an initial denial of statements not admissible in evidence. ${ }^{46}$ Under the in camera procedure provided by the act, on the other hand, the trial court is merely assuming the duty of the prosecutor in Jencks-editing irrelevant matter from relevant documents. Thus, the question before the court is essentially one of determining the scope of government privilege-a judicial determination traditionally made in in camera proceedings. ${ }^{47}$ Moreover, while in theory the right of access to authenticated statements may be identical under the act and the Jencks decision, pragmatically the accused may now obtain more material. For the test of relevancy is no longer applied by the zealous prosecutor but by the presumably impartial trial judge. Similarly, the entire documents are available as a routine matter to the appellate court for review of the trial court's ruling. ${ }^{48}$ Certainly, under Jencks, both the trial

43. See 103 Cong. Rec. 14404, 14408 (daily ed. Aug. 23, 1957). Compare United States v. Schneiderman, 106 F. Supp. 731 (S.D. Cal. 1952) (discussing the standards applicd in camera by the trial judge under the pre-Jencks procedure).

44. See, e.g., remarks of Representative Celler, 103 Cong. REc. 15249 (daily ed. Aug. $30,1957)$.

45. See note 17 supra and accompanying text.

46. See note 21 sipra and accompanying text.

47. See United States v. Cotton Valley Operators Comm., 9 F.R.D. 719 (W.D. La. 1949), aff'd per curiam by an equally divided Court, 339 U.S. 940 (1950) (trial court ordered in camcra examination of privileged government documents to check the prosecution's compliance with a discovery order under Civil Procedure Rule 34), discussed in 4 MOORE, Federal Practice If 26.25, at 1178 (2d ed. 1950); Berger \& Krash, supra note 7; cf. Hickman v. Taylor, 4 F.R.D. 479 (E.D. Pa.), rev'd on other grounds, 153 F.2d 212 (3d Cir. 1945), aff'd, 329 U.S. 495 (1947) (trial court in camera disclosure of lawyer's summaries of witness's statements to sift out and withhold from the moving party the mental impressions of the lawyer, privileged under the attorney-client privilege), discussed in 4 Moore, Federal Practice If 26.23, at 1121 (2d ed. 1950).

48. Under the statute, the appellate court should reverse a conviction whenever the trial court incorrectly denies a defendant a witness's prior statement which relates to the subject matter of his trial testimony. The appellate court should not require any 
and appellate courts could demand and examine government documents in their entirety if the defense established that relevant matter had been wrongfully excised. The statutory procedure, however, restricts the possibility that ignorance of the material's existence or inability to persuade the court of the need to examine the excised matter will preclude the defense from obtaining relevant information. ${ }^{49}$

\section{Unauthenticated Documents}

The act does not explicitly preserve a defendant's right to inspect unauthenticated statements, or summaries of statements. The procedure established by paragraphs (b) and (c) provides for discovery only of those documents conforming to paragraph (e)'s requirements of authenticity. But paragraph (a)'s postponement of inspection until the witness has testified upon direct examination extends to every statement or report. Since no further provision is made for unauthenticated statements or reports, their post-testimony status is unclear.

additional showing that the denial of the defendant's right of inspection was prejudicial as may be suggested by United States v. Miller, 248 F.2d 163, 165 (2d Cir. 1957) (per curiam). For, as the Supreme Court noted in Jencks, "only the defense is adequately equipped to determine the effective use [of such statements] for the purpose of discrediting the Government's witness and thereby furthering the accused's defense." 353 U.S. at $668-69$.

In United States v. Miller, supra, the court refused to grant a retrial of a conviction rendered before and appealed after Jencks. The trial judge had denied the defense statements which, while not inconsistent with the witness's testimony, were relevant thereto. By stipulation, these statements were not made a part of the record on appeal. Accordingly, the court's holding that the trial judge's ruling, though erroneous, was not prejudicial may be viewed as an extension of a waiver theory developed prior to Jencks. See United States v. Ebeling, 146 F.2d 254 (2d Cir. 1944). On the other hand, language in the decision might be interpreted to mean that the statutory requirement of production to the defendant is not absolute. But description of the trial court's conduct as "non-prejudicial" need not produce this result. For Ebeling phrased the waiver doctrine in these terms. And the court may have reverted to such terminology in discussing this aspect of the case without intending a serious interpretation of the statute.

Miller should not be viewed as pronouncing an interpretation of the statute. For such an interpretation would relegate a defendant's right of inspection to its pre-Jentks status. See note 21 supra. Unless the statements contained inconsistencies, as required for their admission in evidence, it would be under Miller mere harmless error to deny the defendant their use. This result, contrary to the intent of Congress and the views of the Supreme Court in Jencks, should not be followed.

For another illustration of the Second Circuit's reluctance to give Jencks retroactive effect, see United States v. Volkell, 251 F.2d 333 (2d Cir. 1958) (waiver approach apparent).

49. The Jencks decision contemplated that the prosecuting attorney would excise irrelevant portions of witnesses' statements. See note 17 supra and accompanying text. However, it is not unlikely that the trial court could have examined the complete document in camera at the request of the defendant to check the compliance of the prosecutor with the court's discovery order. Cf. United States v. Cotton Valley Operators Comm., 9 F.R.D. 719 (W.D. La. 1949), aff'd per curiam by an equally divided Court, 339 U.S. 940 (1950). 
Properly construed, these paragraphs leave unimpaired, after a witness has testified on direct examination, the defendant's access to unauthenticated statements under the Federal Rules of Criminal Procedure and the narrow holding of Jencks. The original proposal of the Department of Justice insulated all unauthenticated statements from discovery at any time. ${ }^{50}$ Paragraph (e)'s retention of similar authenticity requirements should not suggest the identical purpose in the final statute. For the provision in original paragraph (a) confining all discovery to the procedures outlined in the act was expressly replaced with the present provision postponing rather than prohibiting extrastatutory discovery. 51 Spurred to action by the popular misconception that Jencks allowed unlimited discovery, Congress was primarily concerned with insuring that a relevancy limitation was imposed, that the narrow, not the misconceived, holding of Jencks was followed. ${ }^{52}$ Indeed, the over-all congressional intent was to codify Jencks; and Jencks recognized the defendant's right to inspect unathenticated statements..$^{53}$ Admittedly, under the suggested construction, the only relevant distinction between authenticated and unauthenticated documents would appear to lie in the identity of the party charged with excision of irrelevant matter-the court in the former instance, the prosecution in the latter. And this distinction seems purposeless. But in view of the intent to codify the narrow holding of Jencks, immunization of unauthenticated statements appears even less sensible. Most likely, the retention of authenticity requirements in parragraph (e) stems from the demands of time-the final bill was passed on the last day Congress was in session ${ }^{54}$ -rather than a design to confine inspection to authenticated documents.

50. See text at note 38 supra.

51. Apparently ignoring this change in language, a district court recently seems to have construed the present statute as denying unauthenticated documents to the defense. United States v. Abel, S.D.N.Y., Oct. 16, 1957, N.Y. Times, Oct. 17, 1957, p. 1, col. 2. So concluding, the court felt compelled to examine in camera all records of the witness's relevant statements to determine which met If (e)'s definition of authenticity. Certainly, if under the act the relatively simple task of excising those undiscoverable portions of statements which do not logically relate to the witness's testimony rests with the court rather than the prosecution, the prosecution should not be allowed to apply $\llbracket$ (e)'s more nebulous standard of "substantially verbatim" transcript of oral statements if that standard also amounts to an absolute prohibition. But the act, which expressly provides for the former determination, nowhere mentions the obviously necessary procedure authorizing the court to apply these latter standards. Accordingly, the authenticity requirements in II (e) would not appear to continue the rigid prohibition of the original draft.

The Abel case also illustrates the importance of unauthenticated material. Of the 75-100 interviews between the witness and FBI agents involved, "over 6 packets of notes" did not meet If (e)'s requirements while only two statements were authenticated.

52. See notes 32,33 supra.

53. 353 U.S. at 668 . In allowing production of unauthenticated statements, lower courts most probably could distinguish between a record of the witness's report and those portions of reports recording the mental process of the examining agent. Cf. Hickman v. Taylor, 329 U.S. 495, 510-13 (1947), discussed in 4 Moore, Federal Practice $\llbracket 26.23$, at 1121 (2d ed. 1950).

54. Congress adjourned on August 30, 1957. See 103 Cong. Rec. 15246, 15290 (daily ed. Aug. 30, 1957). The bill as reported by the Joint Conference Committee was passed 


\section{Discovery Under the Federal Rules of Criminal Procedure}

Much concerned with the serious effect of the original draft upon the defense rights of discovery under the Federal Rules of Criminal Procedure, Congress strenuously sought to eliminate any such implication in the final formulation of the act. ${ }^{55}$ After successive restrictions, paragraph (a)-originally applicable to "statement[s] or report[s] of any prospective witness or person"-was narrowed to include only "statement[s] or report [s] ... made by a Government witness or prospective Government witness . . . to an agent of the Government."58 Moreover, the Senate expressly provided that documents governed by the act might be subpoenaed if allowable under the federal rules. ${ }^{57}$ While this latter modification was eliminated in joint con-

by the Senate on August 29, 1957, see id. at 15055-56 (daily ed. Aug. 29, 1957), and by the House on August 30, 1957, see id. at 15252-53 (daily ed. Aug. 30, 1957). The Joint Conference Committee had little more than one day in which to reconcile the differences in the house and senate versions of the act, since the House sent the bill to joint conference on August 27, 1957. Id. at 14730-31 (daily ed. Aug. 27, 1957).

The final house debates, following the report of the bill from the Joint Conference Committee, are perhaps the most extreme illustration of the hasty manner in which Congress handled this legislation. Only two Congressmen spoke, Representatives Celler and Keating, both members of the Joint Conference Committee. Id. at 15249-50 (daily ed. Aug. 30, 1957). Representative Celler felt that the Joint Conference Committee's proposal "is for all practical purposes the language and substance of the [weaker] Senate bill." However, Representative Keating expressed a different viewpoint on the proposed legislation: "Mr. Speaker, I think the House should know that I differ markedly and emphatically with the last statement of the chairman of the Committee [Representative Celler], that this bill represents in any way the position of the 55 Members of the House who voted for the substitution of the weak Senate bill. It rather confirms and fortifies the position of the 161 Members who voted for the stronger House bill ... . [The bill reported by the Joint Conference Committee] is a stronger and better bill than that passed by the House ...."Without further discussion or examination of the Joint Conference Committee's proposal, the House enacted it by a vote of 314 to 0 . Id. at 15252-53.

Initially, virtually no hearings were held on the bill in either house. See id. at 14531-32 (daily ed. Aug. 26, 1957) ; id. at 14716 (daily ed. Aug. 27, 1957). And several legislators felt that further consideration of the bill was warranted. See, e.g., remarks of Senator Clark, id. at 13642 (daily ed. Aug. 15, 1957); remarks of Senator McNamara, id. at 14400 (daily ed. Aug. 23, 1957).

55. The effect of the act on the federal rules was the subject of considerable discussion in senate debates. See id. at 14409; id. at 14532-41 (daily ed. Aug. 26, 1957).

56. Compare S. Rep. No. 569, 85th Cong., 1st Sess. 10 (1957) (original draft), with proposal of Senator O'Mahoney, 103 CoNG. Rec. 9896 (daily ed. July 8, 1957) (a later proposal), with S. REP. No. 981, 85th Cong., 1st Sess. 5 (1957) (version passed by the Senate), with the act's final language, quoted in text at note 42 supra.

57. For the text of the bill before the Senate on the day that it passed that house, see 103 Cong. Rec. 14417 (daily ed. Aug. 23, 1957). An attempt to eliminate the reference to the federal rules was defeated. See debate on the Dirksen Amendment, id. at 14542 (daily ed. Aug. 26, 1957). The purpose of the reference was clearly established in the debates: "[W] hether we want to change rules 16 and 17 [of the Federal Rules of Criminal Procedure] is a question entirely separate from the Jencks case and deserves careful study. ... My own judgment is that the rule ought not to be changed when we are discussing the Jencks case." Remarks of Senator Cooper, id. at 14535-36. "Mr. President, 
ference to avoid the suggestion that Congress understood the rules to. be more broadly applicable than judicially recognized, ${ }^{58}$ the textual provision that the act took precedence over "any rule of Court, or procedure to the contrary" was expunged from the draft. And the expressed purpose throughout was to nullify any interference with pre-Jencks discovery under the rules, used primarily by the defense to obtain evidence for his case in chief. ${ }^{50}$

Three federal rules are applicable to discovery of documents in the government's possession. Rule 15(a) allows the defense to deposition a prospective witness apparently unable to attend trial; the government may be required to produce designated papers and documents at the time and place of deposition. ${ }^{00}$ Rule sixteen provides for pretrial discovery of documents and papers belonging to the defendant or taken from third persons by seizure or process. $^{61}$ Finally, rule $17(\mathrm{c})$ authorizes the court to issue subpoenas duces tecum for evidentiary material and, in its discretion, to make the subpoena returnable before trial. ${ }^{62}$

why is the phrase 'except if provided in the Federal Rules of Criminal Procedure' included in the substitute amendment of the Senator from Wyoming? It is included in order to make it abundantly clear that we are not tampering with the Federal Rules." Remarks of Senator Clark, id. at 14537. See also id. at 14409 (daily ed. Aug. 23, 1957).

58. See remarks of Senator Dirksen, id. at 14541 (daily ed. Aug. 26, 1957); remarks of Representative Willis, id. at 14728 (daily ed. Aug. 27, 1957); remarks of Representative Keating, $i d$. at 14729; letter from Attorney General (then Assistant Attorney General) Rogers to Senator Eastland, id. at 14408-09 (daily ed. Aug. 23, 1957).

59. "Mr. CLARK. . . . As I understand the elimination of the reference to Federal Rules, in the redraft presented by the conference committee, does not indicate, and is not intended in any way to indicate, that this measure is intended to amount to a change in any way of the Federal Rules of Criminal Procedure.

“Mr. O'MAHONEY. We are not dealing with the Federal Rules of Criminal Procedure. We are dealing only with the procedure to be followed in the production of these reports." Id: at 15054 (daily ed. Aug. 29, 1957).

60. "If it appears that a prospective witness may be unable to attend or prevented from attending a trial or hearing, that his testimony is material and that it is necessary to take his deposition in order to prevent a failure of justice, the court at any time after the filing of an indictment or information may upon motion of a defendant and notice to the parties order that his testimony be taken by deposition and that any designated books, papers, documents or tangible objects, not privileged, be produced at the same time and place...." Fev. R. Crim. P. 15 (a).

61. "Upon motion of a defendant at any time after the filing of the indictment or information, the court may order the attorney for the government to permit the defendant to inspect and copy or photograph designated books, papers, documents or tangible objects, obtained from or belonging to the defendant or obtained from others by seizure or by process, upon a showing that the items sought may be material to the preparation of his defense and that the request is reasonable ...." FED. R. CRIM. P. 16.

62. "A subpoena may also command the person to whom it is directed to produce the books, papers, documents or other objects designated therein. . . . The court may direct that books, papers, documents or objects designated in the subpoena be produced before the court at a time prior to the trial or prior to the time when they are to be offered in evidence and may upon their production permit the books, papers, documents or objects or portions thereof to be inspected by the parties and their attorneys." FED. R. CRIS. P. 17 (c). 
The act should have little practical effect on the defendant's rights defined by rule 15(a). The primary thrust of the rule-the actual allowance of pretrial deposition-is unaffected by the legislated restrictions. Further, the act's denial of the corollary privilege to examine certain classes of documentary material should derogate from effective deposition but slightly. Admittedly, the scope of material denied the defense is broad. At the time of deposition, in advance of trial and prior to the completion of courtroom preparation, the prosecution could legitimately claim that almost anyone with knowledge of the litigated events might be included within the designation "prospective Government witness." But while the denial is broad quantitatively, only in a limited class of situations do the materials denied constitute a significant prerequisite to successful deposition. Prior statements of the deponent should seldom be of crucial importance to refresh his recollection, the primary use of rule 15(a) matter. ${ }^{63}$ Again, need for such documents to impeach depositioned testimony should be even rarer. A defendant is unlikely to preserve the testimony of a hostile witness for use in an impending criminal prosecution.

Similarly, discovery through rule sixteen should not be restricted by the act. Primarily utilized by the defense to obtain information for preparation of his case in chief, rule sixteen has been interpreted to encompass only tangible evidence existing in a material form when acquired by the government. ${ }^{64}$ The rule is designed to allow the accused those books, business records and documents which he could have examined but for the prior federal acquisition. ${ }^{65}$ This type of material, however, should not be included within the statutory designation "statement or report." Paragraph (a) of the act applies only to statements or reports "made by a witness to a Government agent." And this qualification would appear to exclude documentary material transferred to the prosecution in response to a subpoena or forcibly seized by a government agent.

63. Rules 16 and $17(\mathrm{c})$ are intended to allow the defense to obtain information for use in preparing his case in chief, and for rebutting the prosecution's case. Rule 15(a) serves no comparable purpose. Rather, it is designed to preserve testimony of which the defendant is aware and which may be unavailable for use at trial. The subsidiary provision of that rule is designed to further this goal by making available information which will allow fuller examination. See notes 60-62 supra. For a detailed discussion of the applicability of these rules, see Dession, The New Federal Rules of Criminal Procedure: II, 56 Yale L.J. 197 (1947); Medalie, Federal Rules of Criminal Procedure, Law. Guild Rev., June-July 1944, p. 1; Stewart, Federal Rules of Criainal ProCEDURE (1945).

64. Shores v. United States, 174 F.2d 838, 843-44 (8th Cir. 1949) (rule 16 inapplicable to statements made by persons to government agents); United States v. Chandler, 7 F.R.D. 365, 366 (D. Mass. 1947) (same); United States v. Black, 6 F.R.D. 270, 271 (N.D. Ind. 1946) (same) ; Dession, The New Federal Rules of Criminal Procedure: II, 56 YaLE L.J. 197, 218-20 (1947).

65. See discussion of policy of rule 16 in Shores v. United States, stipra note 64, at 843 . 
On the other hand, the act does limit the utility of rule $17(\mathrm{c})$. By its terms, this rule provides the accused access to documentary information of evidentiary value, including statements and reports, in advance of trial. ${ }^{66}$ It has been construed to allow the accused to examine all relevant statements made to the government by witnesses he can identify before trial. Prior to Jencks, this privilege was available principally in capital cases, ${ }^{67}$ where the government is required by statute to submit to the defense a complete list of all witnesses to be called at trial. ${ }^{68}$ Marshaling support from the spirit of the Jencks decision, two district courts have since extended this practice to noncapital cases, even though no established procedure for designation of witnesses exists and the defendants had not independently ascertained their identity. ${ }^{69}$ The act negates the result in both situations, however, by providing that no statement or report "shall be subject to a subpena . . . until such witness has testified on direct examination in the trial of the case."70 Future pretrial discovery of documents under rule 17 (c) will, accordingly, be limited to those not classifiable as statements or reports of prospective government witnesses.

\section{Statements Showing Bias and Propensity To Lie}

The broad language of the act denies a defendant access to a class of material not specifically contemplated by Jencks yet important for effective

66. For discussions of the scope and effect of rule $17(\mathrm{c})$, see Dession, The New Fcderal Rules of Criminal Procedure: II, 56 YALE L.J. 197, 221-23 (1947); Berge, The Proposed Federal Rules of Criminal Procedure, 42 Micr. L. Rev. 353, 367-68 (1943).

67. Fryer v. United States, 207 F.2d 134 (D.C. Cir. 1953) (capital case); United States v. Bell, 126 F. Supp. 612 (D.D.C. 1955) (same). Pretrial discovery of a witness's statements was also allowed in a noncapital case where the defendant was able to show with certainty that a particular person was to be a prospective witness. See the unreported ruling discussed in United States v. Hiss, 9 F.R.D. 515 (S.D.N.Y. 1949) (motion made prior to new trial following successful appeal by the defendant from his conviction).

6S. 18 U.S.C. $\S 3432$ (1952).

69. United States v. Apex Distributing Co., Crim. No. 49639, W.D. Wash., July 8, 1957; United States v. Hall, 153 F. Supp. 661, 663 (W.D. Ky. 1957) : "The Supreme Court now seems to have reached a conclusion which many of the judges, by their dissenting opinions in former cases, have apparently anticipated; that is, to reduce to an absolute minimum the possibility of a defendant being taken by surprise by the testimony of a government witness during the trial of the case."

See also discussion of these cases in note 34 supra. Other trial courts reached the opposite conclusion on the applicability of the Jencks decision to pretrial discovery. United States v. Anderson, 154 F. Supp. 374 (E.D. Mo. 1957) ; United States v. Benson, 20 F.R.D. 602 (S.D.N.Y. 1957) ; United States v. Sanchez Figueroa, Crim. No.. 32-57, D.P.R. 1957; State v. Thompson, 134 A.2d 266 (Del. 1957). Prior to Jencks, the law seemed settled that a defendant unable definitely to establish that the specified person would be called as a witness could not obtain information before trial. United States v. Brown, 17 F.R.D. 286 (N.D. Ill. 1955) ; United States v. Carter, 15 F.R.D. 367 (D.D.C. 1954); United States v. Brumfield, 85 F. Supp. 696 (W.D. La. 1949).

70. The proponents of the act expressly intended to overrule the effect of Fryer v. United States, 207 F.2d 134 (D.C. Cir. 1953), the first case allowing pretrial discovery of statements in the possession of the government in capital cases. 103 ConG. REC. 1453738, 14541 (daily ed. Aug. 26, 1957). 
cross-examination. Paragraphs (b) and (c), providing the sole procedure for discovery of material within paragraph (e)'s definition of statement, allow the accused only documents which "relate to the subject matter of the testimony of the witness." But a statement may be of aid to cross-examination, and even admissible in evidence to impeach a witness, although not relevant to the subject of his testimony. One prime example may be found in statements showing strong bias, ${ }^{71}$ another in reports indicating a propensity to lie in fact situations analogous to that immediately involved. ${ }^{72}$ The latter statements are evidence of "mythomania"-psychic unbalance resulting in delusions-the chronic prosecutrix in rape cases being particularly illustrative. ${ }^{73}$ Both types of material have long been acknowledged as important sources of impeaching information. In situations comparable to Jencks, involving alleged subversive activities, an acute need for such information exists. The accusing witnesses in this area of especially strong prejudgments have on occasion been recognized to tend to delusions ${ }^{7 t}$ and are commonly informers, spies and agent provacateurs, a class of witnesses whose testimony has traditionally been suspect and only reluctantly admitted in evidence. ${ }^{75}$

71. McHugh v. State, 31 Ala. 317, 320-21 (1858) (general discussion of use of biased statements). See also cases collected in 3 WIGMORE, EvIDENCE $\$ \$ 948,1022$ (3d ed. 1940).

72. People v. Evans, 72 Mich. 367, 379-80, 40 N.W. 473, 478 (1888) (rape by father; former false charges of a similar sort by the prosecutrix against various persons held admissible). See also cases collected in 3 Wignore, Evidence $\$ 963$ (3d ed. 1940); MCCORMICK, EVIDENCE $\$ 163$ n.3 (1954). Documentary and other extrinsic evidence of past acts of misconduct, which merely shows a witness's general bad character rather than his propensity to lie in the given context, is generally inadmissible-nat because it is irrelevant but to avoid cluttering the issues of the trial. However, these facts may be drawn from the witness himself on cross-examination. See 3 WigMore, Euddence $\$ 979$ (3d ed. 1940). See also note 76 infra. Accordingly, false statements of the witness in unrelated subjects should be treated in the same manner as those made in analogous situations. While both are not relevant to the subject matter of the witness's testimony, each is important to effective cross-examination.

73. Discussed in State v. Driver, 88 W. Va. 479, 484-\$6, 107 S.E. 189, 191-92 (1921) (erroneously excluding such evidence). See further discussion and collection of cases in 3 WigMORE, Evidence $\$ \$ 924 a, 934 a, 963$ (3d ed. 1940).

74. The activities of Harvey Matusow, one of the two witnesses involved in the Jencks case, are discussed in United States v. Flynn, 130 F. Supp. 412 (S.D.N.Y. 1955). Newspaper reports assert that the government continued to use Matusow as a witness even after the U.S. Attorney's office in New York received a report indicating that he was suffering from a form of psychoneurosis. See The Nation and $\mathrm{Mr}$. Brownell's " $J_{t}$ slice," The Nation, July 23, 1955, pp. 65, 66; N.Y. Times, April 11, 1955, p. 14, col. 1.

Another government witness accused a waitress, in retaliation for her bringing bastardy proceedings against him, of reporting to the communist party on the eating habits of Pennsylvania Supreme Court Justice Michael A. Musmanno. See Appendices to Petition for Writ of Certiorari, pp. 55-56, Mesarosh v. United States, 352 U.S. 1 (1956).

For a defense of the use of such informants, see Hoover, Hoover Answers Tin Questions on the FBI, N.Y. Times Magazine, April 16, 1950, pp. 9, 31-32; Address before International Association of Chiefs of Police by Assistant Attorney General William F. Tompkins, reprinted in U.S. News \& World Report, Oct. 14, 1955, pp. 107-09.

75. Cf. Donnelly, Judicial Control of Informants, Spies, Stool Pigeons, and Agent Provacateurs, 60 Yale L.J. 1091 (1951); Donner, The Informer, The Nation, April 10, 1954, p. 298. 
The act's insulation of documents facilitating discredit of the testimony of such witnesses seems wholly inadvertent. No recognition of the latent effect was evidenced in committee reports or floor debates. Furthermore, Congress clearly appreciated the importance of relevant statements to effective impeachment of a prosecution witness. By discrediting the witness's testimony on direct examination, evidence of bias or propensity to lie can be equally significant. ${ }^{70}$ The undesirability of denying the accused access to such evidence becomes particularly pronounced when the act is interpreted to allow inspection of unauthenticated statements. While biased and like statements falling without paragraph (e)'s requirement of authenticity would continue to be obtainable, the more reliable documents-those adopted by the witness or verbatim transcripts of his reports-would be denied the accused. ${ }^{77}$ Such denial is unfortunate; if not related to the subject matter of a witness's testimony, these documents are certainly relevant to its effect.

\section{Time of Discovery}

The act rigidly prescribes the time at which the accused may obtain relevant matter; discovery of all statements or reports included within paragraph (a) is postponed until after the witness has testified upon direct examination. To eliminate any hardship which might result were the defense required to conduct his cross-examination immediately, Congress expressly provided for a discretionary postponement subsequent to delivery to the defendant under paragraphs (b) and (c). Presumably, the court could grant a similar recess

76. Wigmore defines the process of impeaching a witness as follows: "A testimonial assertion comes, as evidence, in the same logical form as a circumstantial evidential fact ... i.e., the form of proposed inference is: A asserts the existence of fact $X$; therefore, fact $X$ exists. Hence, the problem of the cogency of this inference involves . . . the question of how many and what other hypotheses there are which explain away the evidential fact of A's assertion as due to some other cause than the existence of fact X. . . The evidential fact is simply that $A$ makes the assertion; the problem is, $C a n$ it be explained away, so that we need not accept fact $X$ as the conclusion? In short, the whole process of Impeachment or Discrediting of a witness, as known to practicioners, is nothing but the general logical process of Explanation." 3 WigmoRe, EvidENCE $\$ 874$ (3d ed. 1940). Clearly, evidence that the witness often contradicts himself need be no more rational an explanation than a showing that the witness is biased against the defendant or accustomed to lie.

Recognizing the importance in impeachment of proving a witness's bias, courts have allowed this fact to be shown by extrinsic evidence. For, as Wigmore observes, "particular conduct and circumstances form the only means practically available for effectively demonstrating the existence of bias." $I d . \$ 948$.

77. The statute may unexpectedly intrude in a multitude of circumstances. For example, in Fisher v. United States, 231 F.2d 99, 104 (9th Cir. 1956), the court held the defendant could prove the amount of pay an informant-witness received from prosecuting authorities by subpoenaing, from the prosecution, receipts for these payments signed by the witness. Such documents would appear to be "statements or reports made to a Government agent," and they do not seem to "relate to the subject matter of the testimony of the witness." 
for perusal of unauthenticated statements obtainable after direct examination under Jencks or federal rule 17 (c).

Nevertheless, such an inflexible procedure may seriously impair the value of a defendant's right of cross-examination. On the one hand, pretrial examination of relevant documents would be of significant aid in utilizing discoverable material. Not only could defense counsel have more leisure in which to examine the statements free from the pressures of the courtroom, but, with knowledge of their content prior to direct examination, he should be better prepared to recognize variances as they develop. ${ }^{78}$ On the other hand, the postponement necessitated by the act's rigid procedure should often minimize the effect of impeaching evidence. While impeachment detracts from the witness's reliability by pointing to circumstances affecting testimonial credibility, this effect is at its maximum when employed immediately after direct examination. At that point, the jury is most aware of the content of the witness's testimony and can best evaluate the total impact of both direct and crossexamination. That the postponement of cross-examination greatly reduces its value has often been stressed. ${ }^{79}$

Moreover, an inflexible statutory rule prescribing the time of disclosure offers little advantage. In an analogous situation-discovery under federal rule 17 (c) - a rigid time of disclosure has been expressly rejected; the Supreme Court ruled that a defendant entitled to subpoena evidentiary material for use at trial may do so earlier in order to expedite proceedings and maximize utility ${ }^{80}$ For discovery under the act, considerations of national security do not seem to require a contrary determination. Early disclosure, of itself, should not jeopardize national security if examination is eventually permissible. And were this time a flexible matter within the court's discretion, discovery could be restricted until the ultimate availability was ascertained with a fair degree of certainty. ${ }^{81}$ Although the time of discovery was not presented

78. The amount of material the defense should be allowed to examine may often be substantial. See United States v. Abel, S.D.N.Y., Oct. 16, 1957, N.Y. Times, Oct. 17, 1957 , p. 1, col. 2, involving summaries and notes of $75-100$ interviews by government agents with the witness.

79. "The cross-examination, or examination by the party not calling the witness, follows immediately the direct examination, in the customary order prescribed by the common law....

"Since the purpose of this immediate sequence is to furnish the tribunal with the means of fixing the net significance of the witness' testimony while the tenor of his direct testimony is fresh in their minds, it seems proper enough to hold that the opponent is entitled to this immediate sequence, in order to expose without delay the weak points of the testimony against him." 6 WigMore, Endence $\$ 1884$ (3d ed. 1940). Moreover, several courts, recognizing the decreased effectiveness of a delayed cross-examination, have held unwarranted postponements of cross-examination to be reversible error. Fralick v. Presley, 29 Ala. 457 (1856) ; State v. Howard, 35 S.C. 197, 14 S.E. 481 (1892); Dillard v. Samuels, 25 S.C. 318 (1886); State v. McNinch, 12 S.C. 89 (1879); of. Willoughby v. Railroad, 32 S.C. 410,11 S.E. 339 (1890).

80. Bowman Dairy Co. v. United States, 341 U.S. 214, 219-20 (1951).

81. This is the effect of the holdings in United States v. Apex Distributing Co., 
in Jencks, subsequent judicial decisions have invoked the decision as support for pretrial discovery of relevant matter. ${ }^{82}$ Such a system of administration would appear preferable to that specified by the act. It could reinforce the rights of the defendant without impinging upon the government's interests.

\section{Enforcement of Discovery Orders}

The limited remedies which the act preserves to a trial court for enforcing discovery orders encourage prosecution impairment of defense rights. While most prosecutors will undoubtedly respect the spirit of the statute, a prosecutor so minded could easily present a witness although he has no intention of honoring the defendant's concomitant right to the witness's prior statements. The likelihood that the defense will not learn of the existence of such statements would seem substantial in most circumstances. Even should their existence become known, the prosecutor has little to lose by refusing to comply with the court's order for production. In such event, the act provides, "the court shall strike from the record the testimony of the witness, and the trial shall proceed unless the court in its discretion shall determine that the interests of justice require that a mistrial be declared."s3 $\mathrm{By}$ this language, Congress clearly intended to deny the trial court power to dismiss the indictment against the accused-the remedy the Supreme Court thought proper in Jencks ${ }^{84}$ - or to hold the government agent who refuses to produce the desired documents in contempt of court-a remedy one district court later utilized to enforce a defendant's right of examination. ${ }^{85}$ The Senate considered and rejected a proposal granting the trial court discretion to "take such other action as the court deems appropriate." the dismissal and contempt remedies would unduly impair law enforcement, and because the Senate felt that declaration of a mistrial gave the prosecu-

Crim. No. 49639, W.D. Wash., July 8, 1957; United States v. Hall, 153 F. Supp. 661 (W.D. Ky. 1957). See discussion of these cases in note 34 supra.

82. See cases cited note S1 supra.

83. 18 U.S.C.A. \& 3500 (d) (Supp. 1957). The full text of the statute is quoted in text at note 42 supra.

S4. 353 U.S. at 672. It is not clear that the Court intended the sanction of dismissal to be automatically applied to all cases in which the prosecution refused to comply with a discovery order. The language of the decision may be limited to cases, like Jencks, where the testimony of the witnesses involved was of crucial importance. See note 10 supra; cf. United States v. Hall, 153 F. Supp. 661 (W.D. Ky. 1957), discussed in text following. Compare United States v. Grayson, 166 F.2d 863 (2d Cir. 1948), where, in a situation similar to Jencks, the court declared that if the government refused to allow the defendant access to privileged documents, an acquittal should be directed for the defendant. This sanction is not mentioned in any other Second Circuit case involving a similar question.

85. United States v. Hall, supra note 84.

S6. See the second version of the bill reported by the Senate Committee on the Judiciary. S. KEP. No. 981, 85th Cong., 1st Sess. 6 (1957). The bill's original language was restored in an amendment offered from the floor during the debates. 103 Conc. REc. 14548 (daily ed. Aug. 26, 1957). 
tion a right of appeal which would not exist if the charges were dismissed, the original language of the act was retained. ${ }^{87}$

These explanations appear erroneous. The prosecution has a right of appeal from a contempt citation, $8 \mathrm{~s}$ and its possibilities of achieving appellate review of a trial court's production order under a dismissal of an indictment seem greater than under the remedies left the court by the act. ${ }^{89}$ While dismissal

87. Id. at 14548. See also id. at 14401-02 (daily ed. Aug. 23, 1957).

88. A contempt citation for failure to comply with a production order, as was decreed in United States v. Hall, 153 F. Supp. 661 (W.D. Ky. 1957), may be appealed by the person cited. 28 U.S.C. $\$ 1291$ (1952). In fact, the court's citation was appealed in that case. Letter from Clerk, U.S. Dist. Ct., W.D. Ky., to the Yale Law Journal, Oct. 25, 1957, on file in Yale Law Library.

89. The statute governing appeals by the prosecution in criminal cases allows the government to appeal to a circuit court, "from a decision or judgment setting aside, or dismissing any indictment or information, or any count thereof except where a direct appeal to the Supreme Court of the United States is provided by this section." 18 U.S.C. $\$ 3731$. (1952). Direct appeals to the Supreme Court are granted from the same decisions or judgments, "where such decision or judgment is based upon the invalidity or construction of the statute upon which the indictment is founded," and from a "decision or judgment sustaining a motion in bar, where the defendant has not been put in jeopardy." Ibid.

Clearly, an order striking evidence or declaring a mistrial is not within the terms of the statute. Cf. Carroll v. United States, 354 U.S. 394 (1957). Moreover, since an appellate court may not review such an order on appeal, the order most probahly cannot be reviewed by extraordinary writ-which federal courts may issue under 28 U.S.C. $\$ 1651$ (1952) only in aid of their appellate jurisdiction. United States v. Bondy, 171 F.2d 642 (2d Cir. 1948) : Mutual Life Ins. Co. v. Holly, 135 F.2d 675 (7th Cir. 1943); 6 Moore, Federal Practice $\llbracket$ 54.10[4], at 88 n.17 (2d ed. 1953); Moore, Judicial Cone If 0.03(51), at 468-69 (1949). But see contra, 6 Moore, Federal Practice $\Uparrow$ 54.10[2], at $69-70$ (2d ed. 1953) ; cf. Maryland v. Soper, 270 U.S. 9 (1926).

The appealability by the government of an order dismissing the charges against the accused is not as clear as the statute's language would suggest. The statute has not been interpreted to require that the dismissal result from defects in the indictment itseli. A dismissal for a collateral reason such as failure to obey an order of the trial cuurt is appealable. United States v. Brodson, 136 F. Supp. 158 (E.D. Wis. 1955) ; if. United States v. Brennan, 214 F.2d 268 (D.C. Cir. 1954). But, in a disclosure of impeachment information situation, the dismissal of the indictment occurs after the trial has begun; and the Supreme Court has declared that a defendant is placed in jeopardy once the trial begins. See Wade v. Hunter, 336 U.S. 684 (1949); Kepner v. United States, 195 U.S. 100,128 (1904). However, as verbalized by the courts, the primary bar of the double jeopardy clause on prosecution appeals has been against appeals after the defendant has been acquitted. See Peters v. Hobby, 349 U.S. 331, 344-45 (1955) ; H.R. REr. No. 45, 77th Cong., 1st Sess. 2 (1941) ; cf. Kepner v. United States, 195 U.S. 100, 133 (1904); United States v. Waters, 175 F.2d 340 (D.C. Cir. 1948). And the courts have not been reluctant to declare an "exception" from the rule that jeopardy attaches when the trial begins for nearly every conceivable circumstance which prevents completion of the trial. E.g., United States v. Perez, 22 U.S. (9 Wheat.) 579 (1824) (discharge of "hung jury"); Wade v. Hunter, supra (interruption of military court by an unexpected advance of enemy troops). Accordingly, Congress might constitutionally be able to give the government a right of appeal from the dismissal of an indictment in circumstances similar to the Jencks case. See United States v. Sanges, 144 U.S. 310 (1892). 
of a case or a contempt citation would seem a harsh remedy where the prosecutor acted in good faith in denying discovery, a provision such as that proposed in the Senate which gives the trial judge full discretion in the remedies to be administered would allow application of a lenient measure in these situations. It could also yield a sufficient sanction to allay manipulation of witnesses in derogation of the accused's rights of discovery. Flexibility so afforded, the accused's interests would be protected without injury to law enforcement.

\section{CONCLUSION}

Although the Supreme Court's opinion in the Jencks case has its areas of partial obscurity, no substantial indication exists that lower courts found it sufficiently broad or vague to necessitate immediate legislation. While in large measure incorporating many of the desirable aspects of the decision, the statute ultimately adopted is not free from defects. To some extent, the shortcomings may be corrected by judicial construction. Thus, the ambiguities occasioned by paragraphs (a) and (e) can be resolved in favor of inspection of unauthenticated statements through extrastatutory channels after the witness has testified. Unfortunately, other reforms may lie beyond the competence of the courts. Still, the rigid time limit on disclosure and the limited enforcement measures-both explicitly provided-should be replaced with a flexible procedure allowing the trial court to gear remedies to the peculiar needs of either the prosecution or the defense. Similarly, statements showing bias or a propensity to lie, inadvertently insulated by the act, should be made subject to discovery. On balance, the statute seems to have created a need for reform more real than that provoking its passage.

Whether $\$ 3731$, quoted supra, gives the government this right is a close question. The bare language of the statute seems to suggest so. For the statute allows an appeal from a decision or judgment sustaining a motion in bar only "where the defendant has not been put in jeopardy." No similar limitation is imposed on appeals from decisions or judgments "dismissing any indictment or information." However, a slightly different carlier version of this section allowed appeals only from orders entered before jeopardy attached. See Taylor v. United States, 207 U.S. 120 (1907) ; United States v. Janitz, 161 F.2d 19 (3d Cir. 1947). As then worded, the statute applied to decisions "quashing, setting aside, or sustaining a demurrer or plea in abatement to any indictment." 18 U.S.C. former $\$ 6 \$ 2$. And the act's present reference to decisions "dismissing any indictment or information" was apparently adopted merely to conform to a change in language of the rules of court procedure and with no intent of changing the meaning of the statute. H.R. REP. No. 304, 80th Cong., 1st Sess. (1948) ; see United States v. Ponder, 238 F.2d 825 (4th Cir. 1956). The solution to this question must remain moot under the present $J_{\text {encks statute. }}$ 